\title{
The BCL-6 POZ domain and other POZ domains interact with the co-repressors N-CoR and SMRT
}

\author{
Khanh D Huynh ${ }^{1}$ and Vivian J Bardwell $1^{1,2,3,4}$ \\ ${ }^{1}$ Biochemistry, Molecular Biology and Biophysics Program, ${ }^{2}$ Department of Biochemistry, ${ }^{3}$ Cancer Center, and ${ }^{4}$ Institute of Human \\ Genetics, University of Minnesota, Minneapolis, Minnesota 55455, USA
}

\begin{abstract}
Virtually all diffuse large cell lymphomas and a significant fraction of follicular lymphomas contain translocations and/or point mutations in the $5^{\prime}$ noncoding region of the putative oncogene BCL-6, that are presumed to deregulate its expression. BCL-6 encodes a $\mathrm{Cys}_{2}-\mathrm{His}_{2}$ zinc finger transcriptional repressor with a POZ domain at its amino-terminus. The POZ (or BTB) domain, a 120-amino-acid motif, mediates homomeric and, in some proteins, heteromeric POZ-POZ interactions. In addition, the $\mathrm{POZ}$ domain is required for transcriptional repression of several proteins, including BCL-6. Using a yeast two-hybrid screen, we identified N-CoR and SMRT as BCL-6 interacting proteins. Both N-CoR and SMRT, which were originally identified as co-repressors for the unliganded nuclear thyroid hormone and retinoic acid receptors, are components of large complexes containing histone deacetylases. We show that the interaction between BCL-6 and these co-repressors is also detected in the more physiologically relevant mammalian two-hybrid assay. The POZ domain is necessary and sufficient for interaction with these corepressors. BCL-6 and N-CoR co-localize to punctate regions of the nucleus. Furthermore, when BCL-6 is bound to its consensus recognition sequence in vivo, it can interact with $\mathrm{N}-\mathrm{CoR}$ and SMRT. We find, in vitro, that $\mathrm{POZ}$ domains from a variety of other POZ domaincontaining proteins, including the transcriptional repressor PLZF, as well as ZID, GAGA and a vaccinia virus protein, SalF17R, also interact with varying affinities with N-CoR and SMRT. We find that BCL-6 POZ domain mutations that disrupt the interaction with $\mathrm{N}$ CoR and SMRT no longer repress transcription. In addition, these mutations no longer self associate suggesting that self interaction is required for interaction with the co-repressors and for repression. More recently $\mathrm{N}-\mathrm{CoR}$ has also been implicated in transcriptional repression by the Mad/Mxi proteins. Our demonstration that N-CoR and SMRT interact with the POZ domain containing proteins indicates that these co-repressors are likely involved in the mediation of repression by multiple classes of repressors and may explain, in part, how POZ domain containing repressors mediate transcriptional repression.
\end{abstract}

Keywords: POZ domain; BCL-6; transcriptional repression; N-CoR; SMRT

Correspondence: VJ Bardwell, Department of Biochemistry, 4-225 Millard Hall, 435 Delaware St. S.E. Minneapolis, MN 55455, USA Received 5 February 1998; revised 9 June 1998; accepted 9 June 1998
Introduction

The BCL-6 gene was identified because its $5^{\prime}$ untranslated region is disrupted by chromosomal translocations associated with non-Hodgkin's lymphomas, in particular diffuse large cell and follicular lymphomas (Baron et al., 1993; Deweindt et al., 1993; Ye et al., 1993; Lo Coco et al., 1994; Miki et al., 1994; Offit et al., 1994; Ohno et al., 1994; Otsuki et al., 1995). These translocations, which juxtapose the intact BCL- 6 coding sequences to one of at least 13 different loci, are believed to cause deregulated expression of the gene (Ye et al., 1995; Chen et al., 1998). In addition, point mutations in the $5^{\prime}$ noncoding sequence of BCL-6 are found in a large proportion $(40-76 \%)$ of these lymphomas (Migliazza et al., 1995). When considered together, translocations and/or point mutations affecting the BCL-6 gene are found in almost all cases of diffuse large cell lymphoma and a large proportion of follicular lymphomas (Migliazza et al., 1995). This supports a model whereby deregulated expression of intact BCL-6 plays a central role in the molecular pathogenesis of these lymphomas. BCL-6 normally is expressed in germinal centers in mature B cells and some CD4 ${ }^{+} \mathrm{T}$ cells (Cattoretti et al., 1995; Flenghi et al., 1995; Onizuka et al., 1995; Pittaluga et al., 1996). It is from these B cells that the BCL-6 associated lymphomas are thought to arise (Stein and Dallenbach 1992). Mice homozygous for a BCL-6 gene deletion have defects in $\mathrm{T}$ cell dependent antibody responses and do not form germinal centers (Dent et al., 1997; Fukuda T et al., 1997; Ye et al., 1997).

BCL-6 is a $\mathrm{Cys}_{2}-\mathrm{His}_{2}$ zinc finger protein belonging to a subclass of zinc finger proteins which contain a POZ domain (also called the BTB or ZIN domain) at the $\mathrm{N}$-terminus and zinc fingers at the $\mathrm{C}$-terminus (Numoto et al., 1993; Bardwell and Treisman 1994; Zollman et al., 1994; Albagli et al., 1995; Dhordain et al., 1995). This 120 amino acid domain was named after the two main classes of proteins in which it can be found, $P O x$ virus and Zinc finger proteins (Bardwell and Treisman, 1994). There are over 20 POZ domain proteins characterized to date and numerous expressed sequence tag (est) sequences corresponding to POZ domain proteins. The function of the pox virus proteins, which lack a DNA binding domain, is unknown (Koonin et al., 1992). Some of the zinc finger proteins such as BCL-6, PLZF, ZF5 and ttk have been shown to function as transcriptional repressors (Xiong et al., 1993; Deweindt et al., 1995; Albagli et al., 1996; Chang et al., 1996; Seyfert et al., 1996; Kaplan and Calame, 1997; Li et al., 1997a). The Drosophila protein 
GAGA, which is also a zinc finger protein, is involved in chromatin remodeling (Tsukiyama et al., 1994; Tsukiyama and Wu, 1995; Wall et al., 1995). One other Drosophila gene, mod(mdg4) or (E(Var)393D), encodes several proteins with the same aminoterminal POZ domain but alternative non-zinc finger carboxy-terminal domains. This gene is an enhancer of position effect variegation (Dorn et al., 1993; Gerasimova et al., 1995).

Two properties have been ascribed to the POZ domain. First, the POZ domain can mediate homomeric as well as heteromeric POZ-POZ interactions (Bardwell and Treisman, 1994; Dhordain et al., 1995; Seyfert et al., 1996). The PLZF POZ domain, which has been studied in more detail, forms a very stable homodimer (Li et al., 1997b). Second, the POZ domains of BCL-6, PLZF and ZF5 have been shown to mediate transcriptional repression (Deweindt et al., 1995; Albagli et al., 1996; Chang et al., 1996; Seyfert et al., 1996; Kaplan and Calame, 1997; Li et al., 1997a).

To identify proteins that interact with BCL-6, and to better understand how BCL-6 mediates repression of its target genes, we have performed a yeast two-hybrid screen. We find that the POZ domain of BCL-6 and several other POZ domains interact with $\mathrm{N}-\mathrm{CoR}$ and SMRT, which were identified as co-repressors of the nuclear hormone receptors (Chen and Evans, 1995; Horlein et al., 1995; Sande and Privalsky, 1996). This suggests that these co-repressors are involved in mediating transcriptional repression by multiple classes of repressors.

\section{Results}

Identification of $N$-CoR and SMRT as proteins interacting with BCL-6 in a yeast two-hybrid screen

The yeast two-hybrid approach was used to screen Daudi cell activator-tagged cDNA libraries for proteins capable of interacting with BCL-6. (Daudi cells are a mature B-cell line that express BCL-6.) Two different bait constructs were made, containing BCL-6 amino acids $1-418$ (POZ Long) or BCL-6 amino acids 74$508(\Delta 74)$ fused to the GAL4 DNA binding domain (DBD). The latter bait is missing the first two-thirds of the POZ domain. Neither bait contains the BCL-6 DNA binding domain (Figure 1a). These bait proteins were used to screen a total of 11 million library transformants for co-activation of the GAL4 responsive His3 and LacZ reporter genes in the yeast strain Y153. We recovered 35 in-frame fusion clones, representing nine different genes, which re-tested positive with the original bait and did not interact with irrelevant test baits. None of these proteins contained a POZ domain (see Materials and methods). In this study we focused on two of these genes, the co-repressors N-CoR and SMRT (Chen and Evans, 1995; Horlein et al., 1995; Sande and Privalsky, 1996), which were identified using the POZ Long bait. A clone containing human $\mathrm{N}-\mathrm{CoR}$, corresponding to amino acids 1019-2061 of murine N-CoR, was identified eight times and a clone containing human SMRT, amino acids 355-670 was identified once (Figure 1b). Neither of these clones contain regions

A

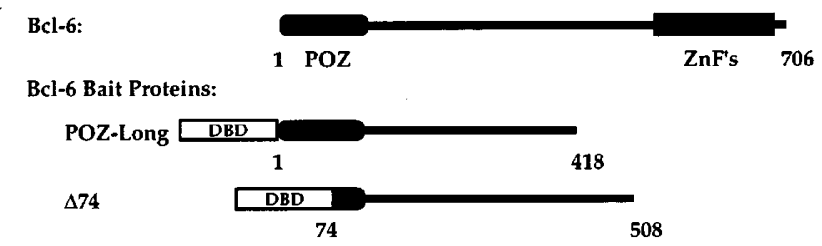

B
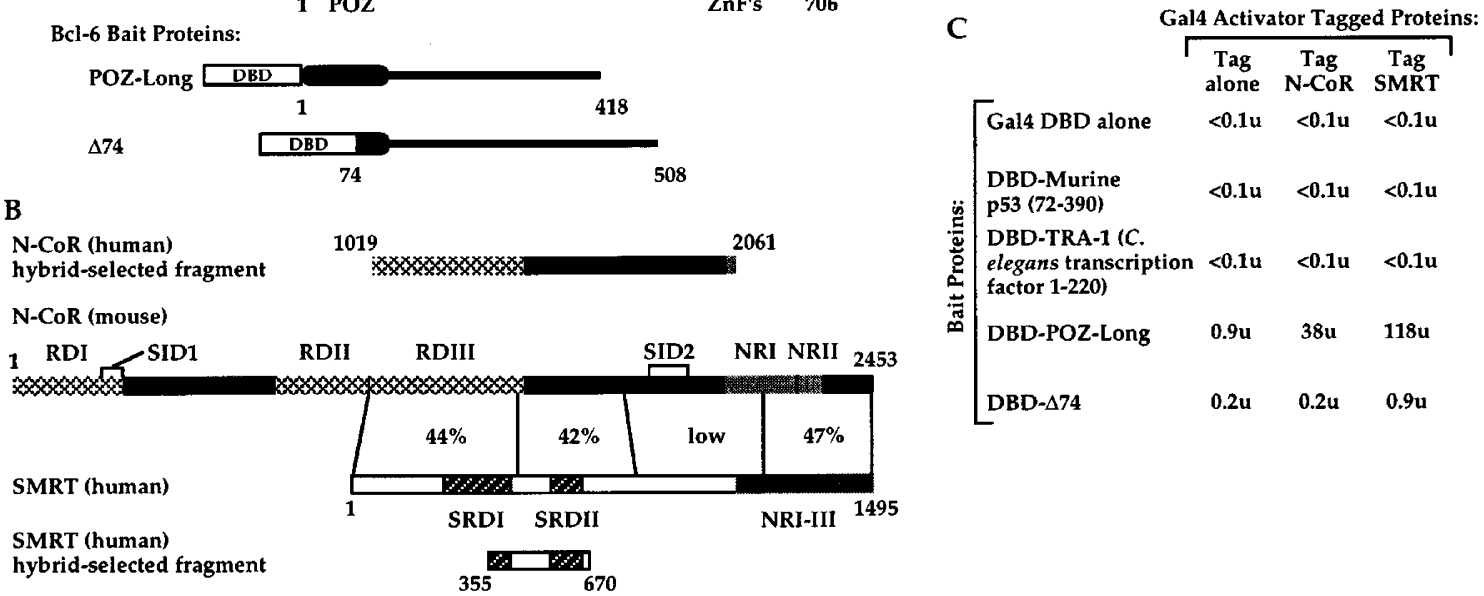

Figure 1 Identification of N-CoR and SMRT as proteins interacting with BCL-6 in a yeast two-hybrid screen. (a) Structures of the full length BCL-6 and the BCL-6 baits. ZnFs, $6 \mathrm{C}_{2}-\mathrm{H}_{2}$ zinc fingers; DBD, GAL4 DNA binding domain (1-147). (b) Structures of NCoR and SMRT fragments identified from the two-hybrid screen in comparison to their full length versions. Depicted are the functional domains that have been previously characterized (Chen and Evans 1995; Horlein et al., 1995; Sande and Privalsky, 1996; Seol et al., 1996; Zamir et al., 1996; Alland et al., 1997; Heinzel et al., 1997; Nagy et al., 1997): RDI-III, N-CoR repression domains; SRDI and II, SMRT repression domains; NRI-III, nuclear receptor interaction domains; SID1 and 2, SIN3 interaction domains. Percent amino acid identity between the two proteins are indicated. Since we do not have a full length human N-CoR clone, amino acid numbers correspond to the murine sequence. The two proteins are highly conserved across this region with the exception of a deletion of murine amino acids 1731 - 1740 in the human clone. (c) Interactions of N-CoR and SMRT with BCL-6 require the POZ domain. S. cerevisiae Y153 strain $\left(\mathrm{Trp}^{-} \mathrm{Leu}^{-} \mathrm{His}^{-} \mathrm{LacZ}^{-}\right.$) was sequentially transformed with the indicated combinations of bait and activator plasmids. The GAL4 activator-tagged N-CoR and SMRT proteins are encoded by the corresponding activator library plasmids identified from the screen. p53 and TRA-1 were used as negative controls. Results are in units of $\beta$-gal activity from liquid culture assays (protocol provided by Clontech) and are the average of a triplicate experiment. The standard deviations for those showing significant activity were less than $2 \%$ 
of N-CoR or SMRT that had been previously identified as being important for interaction with the nuclear hormone receptors (Figure 1b, NRI-III) (Chen and Evans, 1995; Horlein et al., 1995; Sande and Privalsky, 1996; Seol et al., 1996; Zamir et al., 1996) indicating that the region(s) important for interaction with BCL-6 is distinct. The interaction in the yeast two-hybrid assay is specific in that N-CoR and SMRT do not interact with the GAL4 DNA binding domain alone, with the GAL4 baits containing p53(73-290), or with the N-terminal region of the zinc finger transcription factor TRA-1(1-220) (Zarkower and Hodgkin, 1992), (Figure 1c).

To test whether the interaction of BCL- 6 and either of the co-repressors requires the POZ domain, we checked for interaction with the $\Delta 74$ bait. Neither corepressor interacted with this fusion protein, suggesting that the POZ domain is required for interaction in yeast (Figure 1c).

BCL-6 POZ domain interacts with N-CoR and SMRT in the mammalian two-hybrid assay

To determine whether the interactions between BCL-6 and the co-repressors could take place in mammalian cells, we prepared mammalian expression constructs for bait and activator-tagged proteins and carried out a mammalian two-hybrid assay. Since the POZ domain of BCL-6 is required for transcriptional repression (Deweindt et al., 1995; Albagli et al., 1996; Chang et al., 1996; Seyfert et al., 1996), we also wanted to test whether the POZ domain alone was sufficient for the interaction with the co-repressors. Two of the bait constructs were similar to the yeast bait constructs, containing the GAL4 DNA binding domain fused to POZ Long or $\triangle 74$ BCL-6 fragments. In addition, a third construct containing GAL4 fused to BCL-6 amino acids $1-133$ (POZ Short) was generated. The activator-tagged constructs contained the transcriptional activation domain from the herpes virus protein VP16 fused to the N-CoR and SMRT CDNA fragments identified in the yeast two-hybrid screen (Figure 2a). The mammalian two-hybrid assay was carried out by transiently transfecting EB3 cells, a Burkitt's lymphoma cell line which, in our hands, expresses BCL-6 (data not shown), with a GAL4 responsive luciferase reporter and pair-wise combinations of the appropriate bait and activator-tagged expression constructs. Transcription of the reporter gene was assessed by measuring luciferase activity in cell extracts from the transfected cells. Only the POZcontaining bait constructs in combination with VP16 $\mathrm{N}-\mathrm{CoR}$ or VP16/SMRT construct resulted in significant, dose dependent, transcriptional activation. All other combinations of bait and activator constructs resulted in little or no activation of the reporter construct (Figure 2b). Similar POZ-dependent activation was also seen in HeLa cells and K562 cells (see below and data not shown), which express little or no endogenous BCL-6. From these results we conclude that the interaction between BCL-6 and N-CoR(10192061) or SMRT(355-670) can take place in mammalian cells and that the POZ domain, which is required for transcriptional repression (Deweindt et al., 1995; Albagli et al., 1996; Chang et al., 1996; Seyfert et al., 1996), is necessary and sufficient for the interaction.
Interaction of $N-C o R$ and SMRT with BCL-6 bound to its $D N A$ recognition site in vivo

We next wanted to test whether BCL-6, when bound to DNA, interacts with N-CoR and SMRT. This is an important test regarding specificity of the interaction since not all co-repressors interact with DNA-bound nuclear hormone receptors even though they show protein-protein interactions in solution (Zamir et al., 1997). To test this, we needed to first determine the binding specificity of the zinc fingers of BCL-6. We used a binding site selection protocol (Pollock and

A

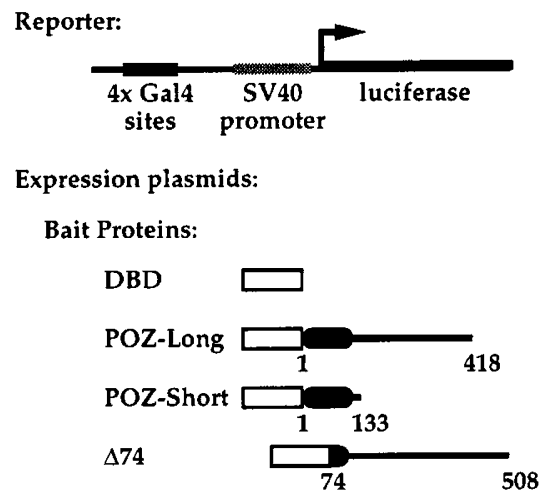

VP16 Activator Tagged Proteins:

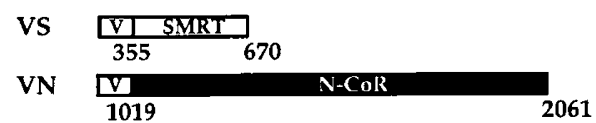

B

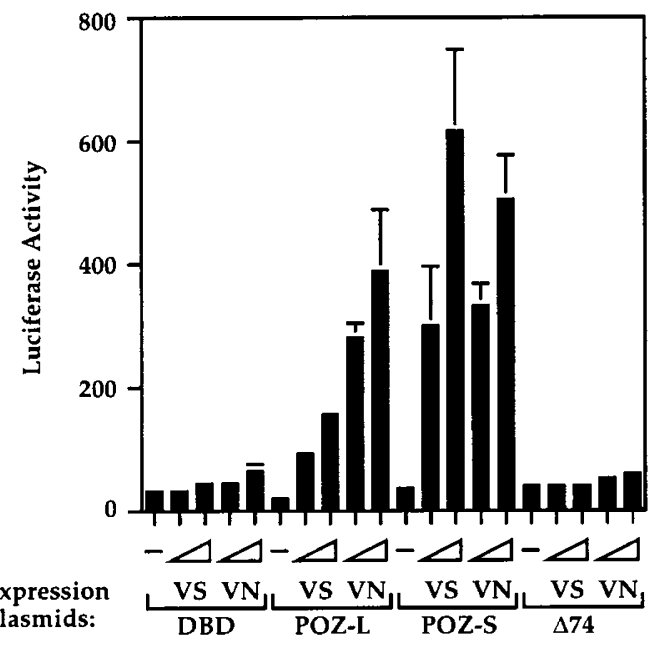

Figure 2 BCL-6 POZ domain interacts with N-CoR and SMRT in the mammalian two hybrid assay. (a) Structures of the luciferase reporter construct (pAH205), bait and activator proteins used in $\mathbf{b}$. The bait proteins correspond to the indicated derivatives of BCL-6 fused to the GAL4 DBD. The activatortagged proteins are VP16 fusions of the cloned SMRT and NCoR fragments. (b) Luciferase and $\beta$-gal assays were conducted on cell extracts from EB3 cells which had been transiently transfected with $10 \mu \mathrm{g}$ of the GAL4 responsive reporter (pAH205), $10 \mu \mathrm{g}$ of the indicated bait expression constructs, either $0,1.5$ or $3 \mu \mathrm{g}$ of the activator-tagged expression constructs for the proteins diagram in a and $2 \mu \mathrm{g}$ of the pEFlacZ plasmid, as a control for transfection efficiency. Results represent the average of a triplicate experiment in which the luciferase activity was normalized to $\beta$-gal activity 
Treisman, 1990) with in vitro translated $\triangle B C L-6$. Forty-seven of fifty oligonucleotides selected in this assay contained variants of the consensus sequence (A/ $\mathrm{G} / \mathrm{T}) \mathrm{TTCCT}(\mathrm{C} / \mathrm{A}) \mathrm{GAAAG}$ or a more degenerate relaxed consensus (Figure 3). Because we sequenced a large number of selected oligonucleotides, after only three rounds of selection, the complexity of the derived matrix gives us a more accurate representation of the spectrum of sites to which the protein will bind than the similar but not identical BCL-6 recognition sites reported previously (Kawamata et al., 1994; Baron et al., 1995; Chang et al., 1996; Seyfert et al., 1996). We confirmed the specificity of the derived consensus site both in vitro, by competition with excess consensus or mutated oligonucleotides in the gel mobility shift assay, and in vivo, by testing BCL-6 binding to reporter constructs containing consensus BCL-6 binding sites or point mutated binding sites (data not shown).

Having determined the BCL-6 DNA recognition sequence, we were able to test in vivo whether BCL-6, when bound to its DNA recognition sequence, interacts selectively with N-CoR, SMRT or both. We first transfected EB3 cells, which contain endogenous BCL6 , with a reporter plasmid in which transcription of the chloramphenicol acetyltransferase (CAT) gene was controlled by four copies of the consensus binding site (WT reporter plasmid) or a mutated derivative binding site (MT1 reporter plasmid), in the absence of plasmids encoding effector proteins (Figure 4a). The levels of transcriptional activation from the WT reporter plasmid are lower than the MT1 reporter plasmid, presumably due to repression by endogenous BCL-6 (Figure 4b). We then tested for interaction between endogenous BCL-6 and the activator-tagged co-repressors. The WT reporter plasmid showed significant transcriptional activation upon co-transfection of VP16/N-CoR and VP16/SMRT (Figure 4b, left panel, compare column 1 versus $2-4$ ), while the MT1 reporter plasmid shows no significant transcriptional activation (Figure 4b, right panel, compare column 1 versus 2-4). This suggests that endogenous BCL-6, when bound to DNA, is capable of interaction with VP16-tagged-N-CoR and SMRT.

We reasoned that if BCL-6 is limiting in these cells, then addition of extra exogenous BCL-6 should potentiate the transcriptional activation seen with a fixed amount of VP16/N-CoR or VP16/SMRT. We therefore transfected increasing amounts of a BCL-6 expression construct in the presence of the VP16/NCoR or VP16/SMRT expression construct (Figure 4b). Strong potentiation of transcriptional activation was

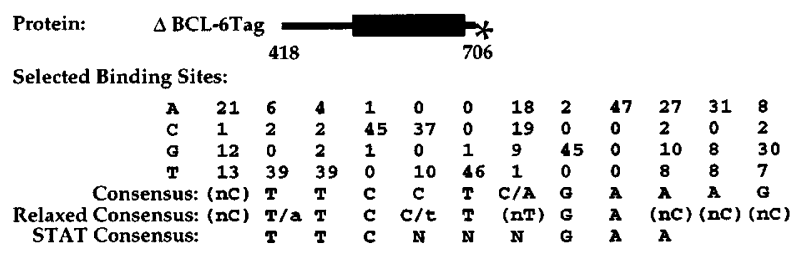

Figure 3 Determination of BCL-6 DNA recognition site in vitro. Structure of the BCL-6 derivative used for the binding site selection. Sequences of 47 oligonucleotides recovered from the site selection were aligned with respect to the derived consensus BCL6 DNA-binding site, and nucleotide frequency at each position is indicated. $\mathrm{nC}$, not $\mathrm{C}$ : $\mathrm{nT}$, not $\mathrm{T}$ seen upon addition of BCL-6. We note that with VP16/ $\mathrm{N}-\mathrm{CoR}$ and $2 \mu \mathrm{g}$ of transfected BCL- 6 we begin to see squelching, presumably due to BCL-6 interacting with VP16/N-CoR off DNA. This is even more pronounced with higher amounts of BCL-6 (data not shown). The transcriptional activity seen upon the addition of VP16/N-CoR or VP16/SMRT is well above that seen with the MT1 reporter and therefore is not just due to relief of BCL-6 repression but rather represents further activation due to interaction of the VP16-tagged corepressors with BCL-6. We conclude that BCL-6 when bound to its recognition sequence can interact with either N-CoR(1019-2061) or SMRT(355-670).

\section{Subcellular distribution of N-CoR and BCL-6}

Endogenous N-CoR, BCL-6 and some other POZ domain containing proteins are found in the nucleus in a diffuse microgranular fashion (Cattoretti et al., 1995; Reid et al., 1995; Soderstrom et al., 1997). Overexpression of these proteins by transient transfection appears to enlarge the granules to produce punctate structures (Bardwell and Treisman, 1994; Dhordain et al., 1995; Soderstrom et al., 1997). To test whether BCL-6 and N-CoR are found in the same granular and punctate nuclear structures, we performed immunofluorescence on HeLa cells transiently transfected with BCL-6 and epitope-tagged N-CoR. We see a range of staining patterns for both proteins, from diffuse microgranular to discrete punctate structures. BCL-6 and N-CoR clearly co-localize to the small and large punctate structures (Figure 4c) suggesting that BCL-6 and $\mathrm{N}-\mathrm{CoR}$ may function or be stored together in these structures.

\section{Interaction of $N-C o R$ and SMRT with BCL-6 in vitro}

To determine whether full length N-CoR and SMRT interact with the BCL-6 POZ domain, and to determine if additional regions of BCL- 6 contact $\mathrm{N}$ CoR or SMRT, we tested for interaction between full length N-CoR and SMRT and subregions of BCL-6 in vitro. Glutathione S-transferase (GST) fusion proteins were generated which contained, in isolation, the POZ domain, the middle region, the zinc fingers, and amino acids 74-508 ( $\Delta 74)$ of BCL-6 (Figure 5a). Approximately equal amounts of each of these fusion proteins as well as GST alone (Figure 5b) were used in GST pull down assays with in vitro translated full length $\mathrm{N}$ CoR and SMRT (Figure 5c). For comparison, we also tested the co-repressor regions identified in the yeast two-hybrid screen, N-CoR(1019-2061) and SMRT(355$670)$. Each of these four proteins interacted most strongly with the POZ domain of BCL-6. None of the co-repressor proteins interacted with the middle region of BCL-6. There was minor but detectable interaction of the zinc finger-containing protein and the $\Delta 74$ protein with all co-repressor proteins except SMRT(355-670). Interaction with the $\Delta 74$ protein was not detected in the mammalian two hybrid assay (see above). The minor interaction with the zinc finger protein was also seen in the presence of $0.5 \mathrm{mg} / \mathrm{ml}$ ethidium bromide (data not shown) suggesting that the interaction is direct and not mediated by DNA. We noted that the intact N-CoR and SMRT interact with BCL-6 more strongly than the truncated fragments 
A Reporters with WT or MT1 Bcl-6 binding sites:

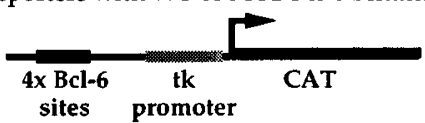

Expression plasmids:

VP16 Activator Tagged Proteins:

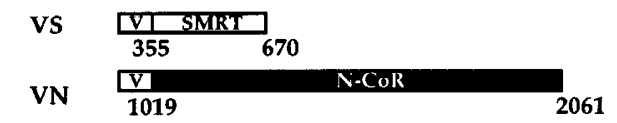

Bcl-6:

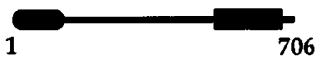

B

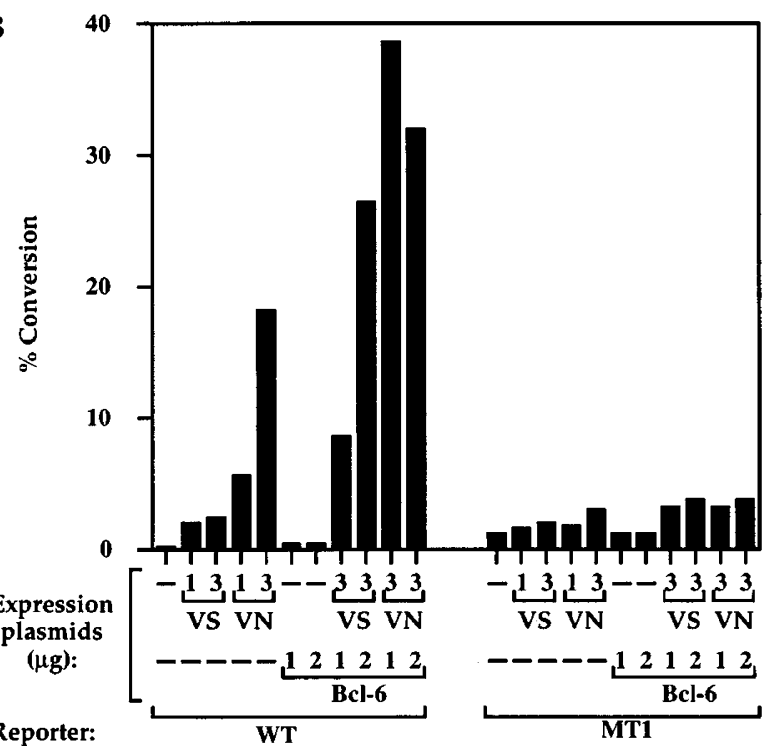

BCL-6
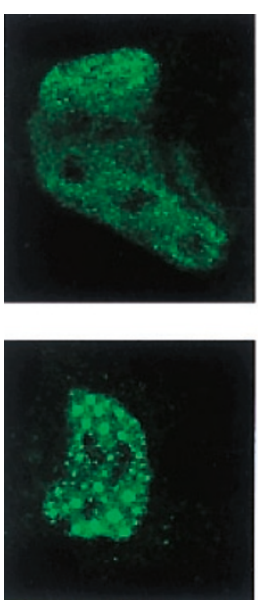

$\mathrm{N}-\mathrm{COR}$
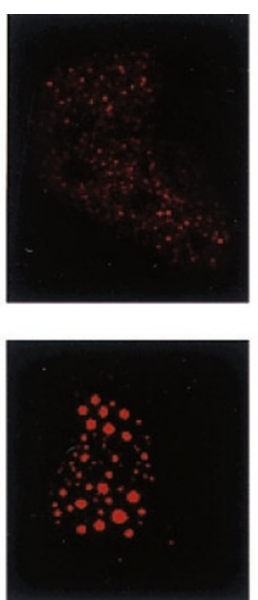

Merged
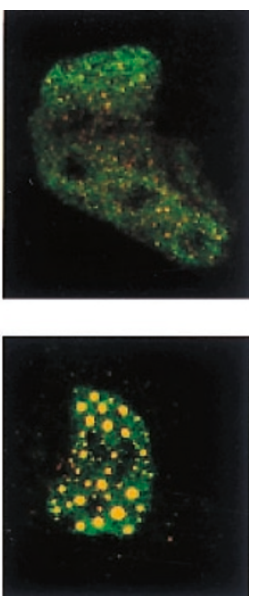

Figure 4 Interaction of N-CoR and SMRT with BCL-6 bound to its DNA recognition site in vivo and co-immunofluorescence of BCL-6 and N-CoR. (a) Structures of the chloramphenicol acetyl transferase (CAT) reporter construct and the proteins used in $\mathbf{b}$. The CAT reporter constructs are controlled by either four copies of the consensus $\left(\mathrm{WT}^{++++}\right)$or mutated $\left(\mathrm{MT}^{++-+}\right)$BCL-6 binding sites; pluses and minuses indicate the orientation of the sites with respect to the consensus sequence. (b) CAT and $\beta$-gal assays were performed on cell extracts from EB3 cells transiently transfected with $10 \mu \mathrm{g}$ of WT (left) or MT1 (right) reporter constructs along with $2 \mu \mathrm{g}$ pEFlacZ and combinations of the indicated amounts (in $\mu \mathrm{g}$ ) of plasmids encoding VP16-tagged corepressors and full length BCL-6. Per cent conversion of chloramphenicol to its acetylated derivatives was quantitated by Phosphorimager scanning and normalized to $\beta$-gal activity. The suggesting that an additional region of $\mathrm{N}-\mathrm{CoR}$ and SMRT may also contact the BCL-6 POZ domain. We conclude that the major co-repressor interaction interface of BCL-6 is the POZ domain.

\section{Interaction of $N-C o R$ and $S M R T$ with other POZ domains in vitro}

To determine whether N-CoR and SMRT interact with POZ domains from other proteins, we again used the GST pull down assay. GST fusion proteins were generated with POZ domains from the additional zinc finger POZ proteins: PLZF (Chen et al., 1993), ZID (Bardwell and Treisman, 1994) and GAGA (Soeller et al., 1993), and from the non-zinc finger POZ proteins: SalF17R from vaccinia virus (Howard et al., 1991), and Protein A, from the $\bmod (\operatorname{mdg} 4)$ gene (Dorn et al., 1993) (Figure 6a).

Approximately equal amounts of each of these fusion proteins (Figure 6b) as well as GST alone were used to test for interaction with in vitro translated intact N-CoR and SMRT. Both proteins interacted with the BCL-6 POZ domain most efficiently but

A GST fusion proteins:
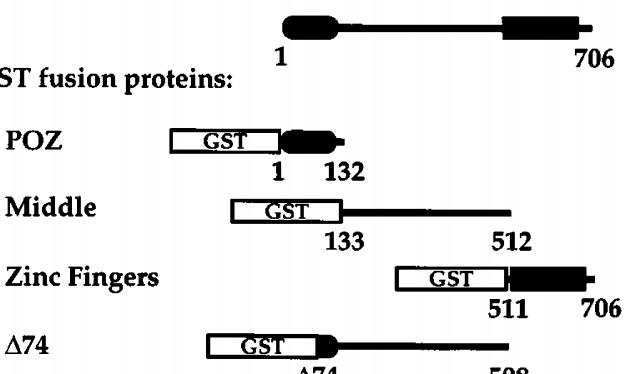

B

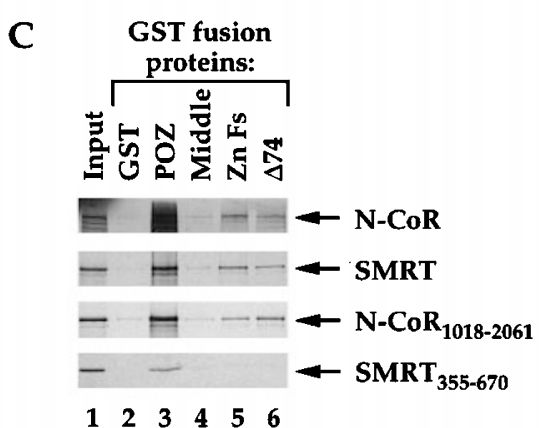

Figure 5 Interaction of N-CoR and SMRT with BCL-6 in vitro. (a) Structures of GST fusion proteins used in (b and c). (b) Coomassie staining of the GST fusion protein preparations used in (c). The middle and $\Delta 74$ fusions were susceptible to partial degradation. (c) GST pulldown experiment. GST protein alone (lane 2) or fused with the indicated BCL-6 derivatives (lanes 3 6), immobilized on beads, were used to 'pulldown' the indicated radiolabeled N-CoR and SMRT derivatives (listed to the right). The input (lane 1) was $1 / 20$ th of that used for each pulldown experiment. Equal volumes of GST fusion protein conjugated beads, which contained approximately $2-4 \mu \mathrm{g}$ of the indicated proteins, were used in the experiment

data displayed are from a single representative experiment. (c) Co-immunofluorescence of BCL-6 and N-CoR. Multiple Z series confocal microscopy images of the given fields were compiled for each image of individual BCL-6 and N-CoR immunofluorescence. The compiled images were merged to detect co-localization 
detectable interaction was seen with all of the other POZ domains, except Protein A (Figure 6c). From these experiments we conclude that N-CoR and SMRT can interact in vitro, with varying avidity and selectivity, with a variety of POZ domains.

\section{POZ domain point mutations eliminate repression}

To more specifically correlate transcriptional repression of BCL-6 with interaction with the co-repressors, we set out to identify point mutations in the POZ domain that failed to interact with the co-repressors and also failed to repress transcription. We compared the sequences of the POZ domains of the proteins that interacted with the co-repressors with the one POZ domain, protein A, which did not interact with the corepressors. We focused on positions that were generally conserved among POZ domains. We identified four amino acids in the amino-terminal region of the POZ domain of protein A that were significantly different from the amino acids found in the other POZ proteins at those positions (Figure 7a). Using site directed mutagenesis we generated three BCL-6 mutations, two single mutations (M1 position 19, L to S, M2 positions 23, $\mathrm{N}$ to $\mathrm{H}$ ) and one double mutation (M3 positions 25 and $26, \mathrm{LR}$ to SL), that code for the amino acid(s) found in protein $\mathrm{A}$ at these positions.

To test the ability of these mutations to interact with the co-repressors, we carried out the mammalian twohybrid assay in HeLa cells. The reporter, the GAL4

A

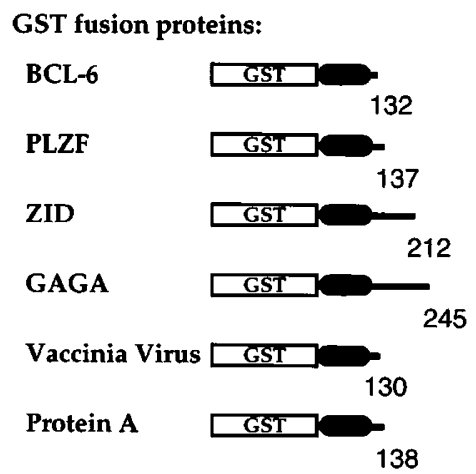

B

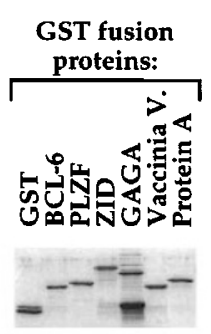

1234567

C

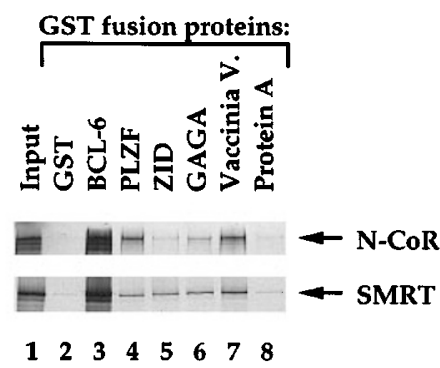

Figure 6 Interaction of N-CoR and SMRT with other POZ domains in vitro. (a) Structures of GST fusion proteins used. (b) Coomassie staining of GST fusion preparations used in (c). GAGA fusion was highly susceptible to degradation. (c) GST pulldown experiment. GST alone (lane 2). GST fused with POZ domains of the indicated proteins (lanes 3-8). The input (lane 1) was $1 / 10$ th of that used for each pulldown experiment. Equal volumes of GST fusion protein conjugated beads, which contained approximately $2-4 \mu \mathrm{g}$ of the indicated proteins, were used in the experiment
DBD, the POZ Short bait and VP16-tagged corepressor expression plasmids were identical to those used in Figure 2. In addition we used POZ short bait expression plasmids containing the mutations M1, M2, and M3. In this assay the bait protein M2 interacted with both VP16-tagged co-repressors with the same efficiency as the intact POZ Short bait. In contrast, M1 and M3 failed to interact with the co-repressors (Figure 7b). By Western analysis, using a GAL4 DBD antibody, all four POZ bait proteins were expressed at equal levels (data not shown).

To test the ability of these mutated POZ domains to repress transcriptions we co-transfected a SV40 enhancer driven, GAL4 responsive luciferase reporter together with each of the POZ Short baits used above. The intact POZ domain and $\mathrm{M} 2$ repress transcription in a dose dependent and DNA binding domain dependent manner. M1 and M3, the mutants that did not interact with the co-repressors, do not effectively repress transcription (Figure $7 \mathrm{c}$ ).

Since the BCL-6 POZ domain can self associate we wanted to test whether these mutations also affect the POZ-POZ interaction. We used an immunoprecipitation assay, in which myc-epitope-tagged, POZ Short, and non-tagged, POZ Long, proteins were produced by co-translation and immunoprecipitated using the 9E10 $m y c$ epitope antibody. In this assay co-precipitation of the non-tagged protein is indicative of a stable interaction between the POZ domains (Bardwell and Treisman, 1994). Constructs encoding both POZ Short and POZ Long version of each of the three-point mutations, M1, M2 and M3, were generated. Using the co-immunoprecipitation assay, each mutation was tested for homomeric interaction and compared to the homomeric interaction of the intact BCL-6 POZ domain. Self association of the M2 POZ domain was equivalent to that of the intact POZ domain (Figure $7 \mathrm{~d}$, lanes 5 and 7). In contrast POZ domain mutants M1 and M3 failed to show significant self association (Figure 7d, lanes 6 and 8). The small amount of coimmunoprecipitated M1 and M3 POZ Long protein is likely to be non-specific binding since it is also seen in a mock co-immunoprecipitation in the absence of the POZ-tag protein (data not shown). In summary, those POZ domain mutants, M1 and M3, which fail to self associate, fail to interact with the co-repressors and fail to repress transcription.

\section{Discussion}

Five lines of evidence presented here support the conclusion that the co-repressors N-CoR and SMRT interact with BCL-6. First, a homologous subregion of both proteins was identified in a yeast two-hybrid screen as interacting specifically with BCL-6 (Figure 1). Second, the interaction was also detected in the more physiologically relevant mammalian two-hybrid assay, where we demonstrated that the POZ domain of BCL6 is both necessary and sufficient for this interaction (Figure 2). Third, the interaction can take place in vivo when BCL-6 is bound to its DNA recognition site (Figure 4). Fourth, BCL-6 and N-CoR co-localized to punctate regions of the nucleus. Fifth, interaction was detected between purified BCL- 6 derivatives and in vitro translated full length co-repressors (Figure 5). 
$\mathbf{A}$

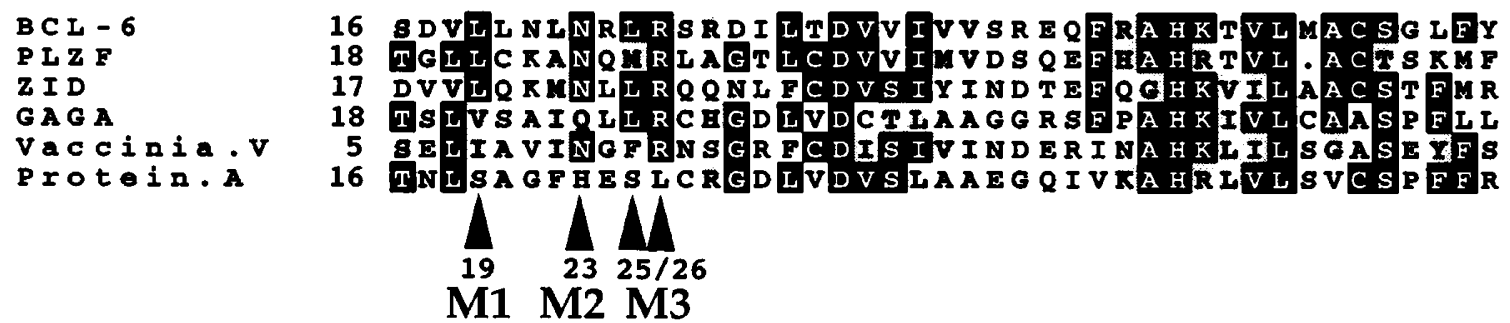

B

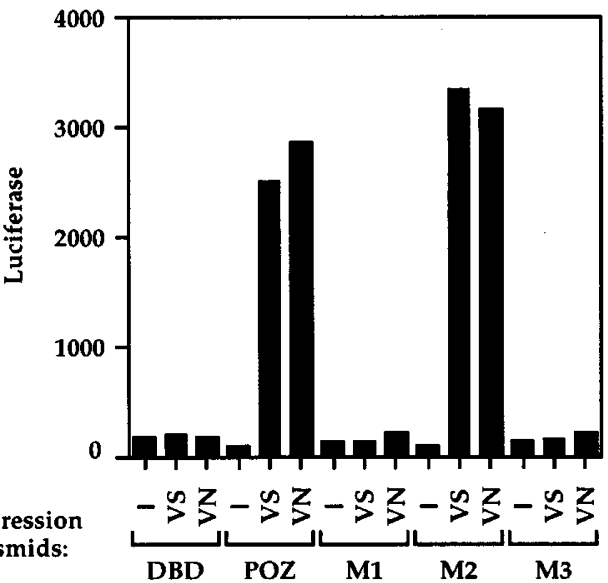

C

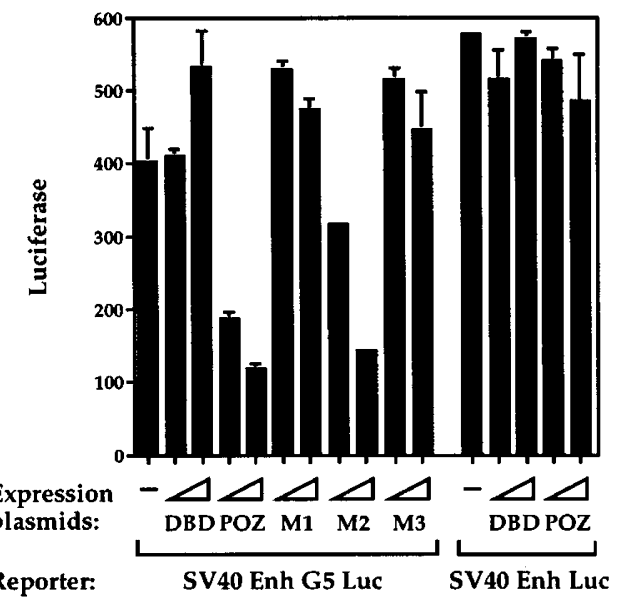

$\mathbf{D}$
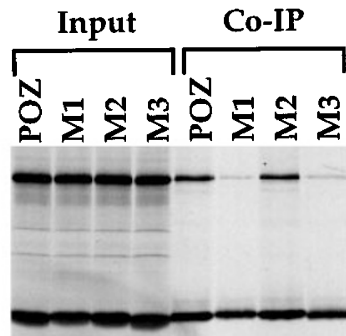

POZ-Long

$\begin{array}{lllllllllll}1 & 2 & 3 & 4 & 5 & 6 & 7 & 8 & -\end{array}$

Figure $7 \mathrm{POZ}$ domain point mutations abrogate interaction with co-repressors, transcriptional repression and self association. (a) Alignment of the amino-terminal region of the POZ domains. The full 120 amino acid POZ domain is not shown. Arrows indicate the positions that were targeted for mutagenesis. Amino acid residues of BCL-6 at those positions were changed to those of Protein A. M1: L19S; M2: N23H; M3: L25S, R26L. (b) Interactions of POZ mutants in mammalian two-hybrid. Luciferase and $\beta$-gal assays were conducted on cell extracts from HeLa cells which had been transiently transfected with $500 \mathrm{ng}$ of the GAL4 responsive reporter (pAH205), $50 \mathrm{ng}$ of the bait expression plasmids [GAL4 DBD alone (DBD) or fusions with an intact POZ-Short domain (POZ) or POZ-Short domains with the indicated mutations (M1, M2, M3)], either 0, or $100 \mathrm{ng}$ of the activator-tagged expression plasmids (VS and VN) and $25 \mathrm{ng}$ of the pCMVlacZ plasmid, as a control for transfection efficiency. The reporter, the GAL4 DBD, the POZ bait (POZ-Short) and the VP16-tagged co-repressor expression plasmids, VS and VN were those used in Figure 2. Data displayed are representative of two independent experiments in which luciferase activity was normalized to $\beta$-gal activity. (c) Transcriptional repression activity by POZ mutants. Luciferase and $\beta$-gal assays were conducted on cell extracts from HeLa cells which had been transiently transfected with $50 \mathrm{ng}$ of the indicated reporter plasmids, either 2.5 or $10 \mathrm{ng}$ of the indicated GAL4 DBD fusions which were used as baits in $\mathbf{b}$, and $25 \mathrm{ng}$ of pCMVlacZ plasmid. Results represent the average of a triplicate experiment in which the luciferase activity was normalized to $\beta$-gal activity. (d) Co-immunoprecipitation of POZ mutants. Pairwise combinations of the ${ }^{35}$ S-methionine-labeled nontagged (POZ-Long) and 9E10 epitope-tagged (POZ-Short-tag) proteins were produced by co-translation. Data shown is a $15 \%$ SDS-PAGE analysis of proteins recovered from immunoprecipitation using 9 E10 antibody (lanes $5-8$ ) and $20 \%$ of the input (lanes $1-4$ ) 
Very recently, others have reported interactions between PLZF and SMRT and N-CoR, and BCL-6 and SMRT (Dhordain et al., 1997; Hong et al., 1997; Grignani et al., 1998; Guidez et al., 1998; He et al., 1998; Lin et al., 1998). Here we show that BCL-6 and other POZ domain containing proteins interact with both SMRT and N-CoR suggesting that the interaction of POZ domains with N-CoR and SMRT is a general phenomenon (Figure 6).

POZ domains from several proteins have previously been shown to mediate transcriptional repression. Our identification of both co-repressors in the yeast twohybrid screen and our demonstration that the POZ domain is necessary and sufficient for interaction with these co-repressors strongly suggests that these corepressors are involved in BCL-6 transcriptional repression. In addition, we have identified point mutations in the BCL-6 POZ domain that fail to interact with the co-repressors, fail to repress transcription and fail to self associate. The simplest interpretation of these data is that the co-repressors interact with a dimerized POZ domain and that interaction with the corepressor(s) is required for repression.

N-CoR and SMRT (also called TRAC-2) were originally identified as co-repressors for the unliganded thyroid hormone and retinoic acid receptors (Chen et al., 1995; Horlein et al., 1995; Sande et al., 1996). N-CoR has also been implicated in transcriptional repression by Mad and Mxi (Alland et al., 1997; Heinzel et al., 1997). Our demonstration that these co-repressors can interact with the POZ domains of BCL-6, and other POZ domain proteins suggests these co-repressors are likely to be involved in repression by a variety of classes of transcriptional repressors. This is analogous to the situation with the co-activators CBP and p300, which are involved in transcriptional activation by several sets of transcriptional activators (Goldman et al., 1997).

Recent studies have shown that N-CoR and SMRT can be found in multisubunit repressor complexes together with $\mathrm{mSin} 3$, a histone deacetylase, and a number of other proteins (Alland et al., 1997; Heinzel et al., 1997; Nagy et al., 1997; Zhang et al., 1997). The presence of deacetylase activity in these repressor complexes suggests a model in which repression by sequence-specific transcription factors can be mediated, at least in part, by recruitment of a deacetylase (Alland et al., 1997; Heinzel et al., 1997; Nagy et al., 1997; Zhang et al., 1997). We speculate that BCL-6 and other POZ-containing repressors also may modulate transcription in a similar manner. Indeed, very recently weak interaction between PLZF and Sin3A, Sin3B and HDAC1 have been detected by GST pull down (Guidez et al., 1998; Lin et al., 1998).

We have shown that the POZ domain of BCL-6 is the major interaction interface for both $\mathrm{N}-\mathrm{CoR}$ and SMRT. Interaction of the BCL-6 POZ domain with the intact co-repressors was stronger than with the truncated co-repressors, suggesting that other regions of the co-repressors may stabilize binding to the POZ domain. In the case of PLZF, a second carboxyterminal region of SMRT contributes to the interaction with that POZ-containing protein and regions outside of the POZ domain also contribute to interaction of PLZF with the co-repressors. (Hong et al., 1997; Grignani et al., 1998). Further deletional analyses will be necessary to specifically identify all regions of the co-repressors that contribute to the interaction with the BCL-6 POZ domain.

In the GST pull down assay, the co-repressors interact more strongly with the BCL-6 POZ domain than with POZ domains from other proteins. This might reflect the relative strengths of the proteins as repressor. Alternatively, interaction in vivo may be stronger due to additional interacting domains or additional components of the co-repressor complexes. In support of this, Hong and coworkers also see weak in vitro PLZF - SMRT interaction but in vivo, in a twohybrid analysis, the interaction is as strong as the RAR-SMRT interaction (Hong et al., 1997).

The role the co-repressors play with other POZ domain containing proteins in other systems and species is not yet clear. GAGA, which can function as a transcriptional activator (Soeller et al., 1993), is also capable of recruiting the NURF chromatin remodeling complex to the hsp70 gene (Tsukiyama and $\mathrm{Wu}, 1995$; Wall et al., 1995). Whether GAGA can recruit co-repressor complexes and NURF complexes under different circumstances remains to be investigated. The Protein A POZ domain is derived from the Drosophila mod(mdg4) gene which plays a role in position effect variegation (Dorn et al., 1993; Gerasimova et al., 1995). The lack of interaction of Drosophila protein A may reflect a subtle speciesspecific differences between human co-repressors and putative Drosophila co-repressors. If the interaction of POZ domains and co-repressors is universal, it is possible that recruitment of co-repressors and deacetylases may somehow be involved in position effect variegation. The function of the vaccinia virus protein SalF17R (Howard et al., 1991) is unknown, so the relevance of the in vitro interaction is unclear.

Translocations involving PLZF and BCL-6 have been implicated in cancer. In rare cases of acute promyelocytic leukemia, PLZF is fused to the retinoic acid receptor (RAR), generating a protein that can interact with co-repressors via two domains, (Hong et al., 1997) which may contribute to the oncogenic potential of this fusion protein. Indeed, while this paper was under review, several groups have demonstrated that the interaction of PLZF with N-CoR and SMRT is retinoic acid insensitive and this provides an explaination as to why patients with the PLZF-RAR fusion are not responsive to retinoic acid treatment (Grignani et al., 1998; Guidez et al., 1998; He et al., 1998; Lin et al., 1998). BCL-6 is presumed to be aberrantly expressed in diffuse large cell lymphomas because of the translocations and point mutations found in the $5^{\prime}$ non-coding region of the gene in these lymphomas (Migliazza et al., 1995; Ye et al., 1995). Since the BCL-6 POZ domain shows the highest affinity of the POZ domains tested, it is conceivable that inappropriately expressed BCL-6 may sequester co-repressor complexes and therefore cause derepression of other key genes involved in growth control or B-cell maturation. Alternatively, the aberrant expression of BCL-6 may lead to inappropriate repression of such key genes, via recruitment of co-repressor complexes.

To date, only two potential BCL-6 responsive genes have been identified (Baron et al., 1997; Dent et al., 1997). However, we note that the BCL-6 binding site resembles that of the STAT proteins (Figure 3). In 
addition, the WT but not the MT1 BCL-6 binding site can compete for gamma interferon induced protein complexes (which include STAT proteins) that bind to the IRF-1 GAS element and in vitro translated $\triangle \mathrm{BCL}-6$ can bind to the IRF-1 gas element (K Gustafson and V Bardwell, unpublished data). These findings suggest that BCL-6 may repress some genes regulated by the STAT proteins. Recently, Dent and coworkers have suggested a similar model and have shown that the STAT6 responsive gene, $\mathrm{CD} 23$, can be down regulated by BCL-6 (Dent et al., 1997). The information derived from our comprehensive site selection and the similarity of the BCL-6 binding site to the STAT proteins' recognition sequence may help in the identification of other genes regulated by BCL- 6 that may be involved in the generation of lymphomas.

Further elucidation of the molecular mechanism of transcriptional repression by BCL-6 with N-CoR and SMRT will help us to understand how BCL-6 functions normally and in the generation of cancer. We note that the central region of BCL-6, that is also found to be important for transcriptional repression (Albagli et al., 1996; Chang et al., 1996), may interact with some of the other candidate BCL-6 interacting proteins identified from our studies. Further analyses of the interactions of BCL-6 with these other candidates may reveal additional mechanisms through which BCL-6 acts to repress transcription.

\section{Materials and methods}

\section{Plasmids}

Construction was by standard methods; all plasmid structures were verified by appropriate restriction digest or sequencing. Details of plasmid constructions, beyond what is described below, are available on request.

Yeast two-hybrid BCL-6 baits: BCL-6 POZ Long, codons $1-418$ were inserted into pGBT9 (Clontech); BCL-6 $\Delta 74$, codons 74-508 were inserted into pAS1 (Durfee et al., 1993) (a gift of S Elledge). Other baits: GAL4-p53 (Clontech) and GAL4-TRA-1 (a gift of D Zarkower). Activator Library: cDNAs were made from Daudi cell PolyA + RNA using the Superscript Choice System (GibcoBRL) and inserted into pACTII, a derivative of pACT (Durfee et al., 1993) in which the polylinker was modified (a gift of S Elledge). We call this the C-terminal library since the cDNAs are inserted Carboxy-terminal to the GAL4 activation domain in pACTII. We also made and used an N-terminal library, details of the construction of which are available upon request. Both SMRT and NCoR clones were isolated from the C-terminal library screen.

Mammalian two-hybrid and transcriptional repression analyses Luciferase reporter plasmid for mammalian two-hybrid analyses (pAH205), containing $4 \times$ GAL4 binding sites was kindly provided by $\mathrm{D}$ Bernlohr. This plasmid is a derivative of the pGL3-promoter plasmid (Promega). Luciferase reporter plasmid for repression analyses was constructed by excising a fragment containing five GAL4 binding sites from G5E1bLuc (Hsu et al., 1994) (generously provided by R Baer) and inserting it into pGL3-Control plasmid (Promega). This plasmid contains the SV40 enhancer located downstream of the luciferase gene. Mammalian CMV expression vector containing GAL4 DNA binding domain $(1-147)$ (Wilkinson and
Towle, 1997) was a gift from H Towle. BCL-6 derivatives were inserted into this vector to generate the various GAL4DBD - BCL-6 fusions. Expression construct containing herpes virus VP16 activation domain (AD) was made by inserting VP16 AD (codons 410-490) into a modified pEF-BOS (Mizushima and Nagata, 1990) vector, pEFplink2 (a gift from R Marais). N-CoR(1019-2061) and SMRT(355-670) fragments, excised from their corresponding yeast activator library vectors were inserted into this vector to generate the VP16 AD fusions. pEFlacZ and pCMVlacZ used as internal controls for transfection efficiency, were gifts of $\mathrm{R}$ Marais and $\mathrm{H}$ Towle respectively.

GST fusion proteins POZ domain cDNA sequences, derived from previously used plasmids (Bardwell and Triesman, 1994) or PLZF cDNA (a gift of A Zelent) were cloned into pGEX20T, a modified version of pGEX2T (Pharmacia) which contains the plink polylinker (Dalton and Treisman, 1992).

In vitro transcribed/translated proteins Expression plasmids for full length $\mathrm{N}-\mathrm{CoR}$ (pCMX-N-CoR) (Horlein et al., 1995) and SMRT (pCMX-SMRT) (Chen and Evans, 1995) were generously provided by $M$ Rosenfeld and $\mathrm{R}$ Evans respectively. Expression constructs for N-CoR(10192061) and SMRT(355-670) were made by excising the fragments from their corresponding activator library vectors and cloning them into $\mathrm{T} 7 \beta \mathrm{plink}$ (Dalton and Treisman, 1992). Expression plasmids for BCL-6 derivatives were in T7 $\beta$ plink and a modified version, containing a carboxy-terminal 9E10 Myc epitope-tag (Dalton and Treisman, 1992; Bardwell et al., 1994), which was used for immunoprecipitation of $\triangle B C L-6$ in the binding site selection and POZ-Short-tag in co-immunoprecipitation assays.

CAT assays CAT reporter plasmids containing four copies of either consensus or mutated BCL- 6 binding sites were made by inserting the corresponding double-stranded oligonucleotides (WT: 5'-CTAGATTCCTCGAAAGT-3'; MT1: 5'-CTAGATTCCCCTCAAGT-3', BCL-6 site is underlined) into pBLCAT5 vector (Boshart et al., 1992). Full length BCL-6 (amino acids 1-706) was inserted into the expression vector pEFplink2.

Immunofluorescence analyses Full length BCL-6 expression plasmid and pCMX-N-CoR were described above. pCMX-N-CoR contains two copies of the 'FLAG' epitopetag fused to the carboxy-terminal of the N-CoR cDNA.

\section{In vitro protein-protein interaction assays}

GST pull down experiments were modified from (Zamir et al., 1996). E. coli strains harboring various GST fusion constructs were grown at $37^{\circ} \mathrm{C}$ to mid $\log$ phase and induced with $0.25 \mathrm{~mm}$ isopropylthiogalactopyranoside (IPTG) for $3 \mathrm{~h}$. Cells were lysed in $1 \times$ phosphate buffered saline (PBS) plus protease inhibitors $(1 \mu \mathrm{g} / \mathrm{ml}$ aprotinin, $1 \mu \mathrm{g} / \mathrm{ml}$ leupeptin, $1 \mu \mathrm{g} / \mathrm{ml}$ pepstatin, $0.5 \mathrm{~mm}$ PMSF, and $1 \mathrm{~mm}$ benzamidine), by the French press method (@ 1000 p.s.i.). TritonX-100 was added to a final concentration of $1 \%(\mathrm{vol} / \mathrm{vol})$ to the total lysate to aide in solubilization of the fusion proteins. The GST fusion proteins were purified by affinity chromatography on glutathione-agarose beads (Pharmacia) and retained as a $50 \%$ slurry in PBS plus protease inhibitors. Ten microliters of GST beads (pre-loaded with $2-4 \mu \mathrm{g}$ of GST fusion proteins) were incubated in $45 \mu \mathrm{l}$ binding buffer $(20 \mathrm{mM}$ HEPES pH 7.9, $100 \mathrm{mM} \mathrm{KCl,} 0.1 \%$ Nonidet P-40 (NP-40), $10 \%$ glycerol, $2 \mathrm{~mm}$ EDTA, $0.5 \%$ nonfat dry milk, $5 \mathrm{~mm}$ dithiotreitol (DTT), and protease inhibitors) with $5 \mu \mathrm{l}$ in vitro synthesized ${ }^{35} \mathrm{~S}$-methionine radiolabeled (TNT coupled 
reticulocyte lysate system; Promega) SMRT or N-CoR or the truncated derivatives. After a $1 \mathrm{~h}$ incubation at room temperature, the beads were washed three times with binding buffer. The bound proteins were eluted by boiling beads in $2 \times$ SDS-gel loading buffer and fractionated on 8 or $12 \%$ SDS-polyacrylamide gels. Co-immunoprecipitation experiments were performed as described (Bardwell and Treisman, 1994) with the following modifications: In vitro synthesized ${ }^{35}$ S-methionine labeled BCL-6 proteins were produced using the TNT coupled reticulocyte lysate system (Promega). Immunoprecipitates were washed twice with a modified RIPA buffer (20 mM Tris- $\mathrm{HCl}$ pH 8.0, $500 \mathrm{~mm}$ $\mathrm{NaCl}, 0.5 \%$ deoxycholate, $0.5 \%$ NP-40, $0.1 \%$ SDS, $10 \%$ glycerol, and $10 \mathrm{mM}$ EGTA).

\section{Yeast two-hybrid screen}

To conduct the screens, Saccharomyces cerevisiae Y153 reporter strain $\left(\mathrm{Trp}^{-} \mathrm{Leu}^{-} \mathrm{His}^{-} \mathrm{LacZ}^{-}\right.$) was sequentially transformed with the bait constructs and the activator library and plated on minimal media lacking tryptophan, leucine and histidine, and containing $50 \mathrm{~mm}$ 3-aminotriazole. Yeast two-hybrid manipulations were carried out as described by Clontech. Positive colonies, $\mathrm{His}^{+}$and $\mathrm{LacZ}^{+}$ (blue colonies in filter lift assays) were picked and cured of the bait plasmids by growth on SC medium lacking leucine. The activator plasmids were then isolated from yeast and transferred to E. coli for further manipulations using the Yeast DNA Isolation System (Stratagene). The screens were carried out on a pale blue background since the baits alone gave a low level of transcriptional activation of the integrated LacZ reporter. In addition to the 9 in-frame fusion proteins described in the results we also recovered two clones containing BCL- 6 itself. In these clones the activation domain and BCL-6 were not in frame and were separated by the $5^{\prime}$ untranslated region of BCL-6. We presume a low level of frame shift suppression occurred in this region giving rise to enough fusion protein capable of activating transcription through a homotypic POZ-POZ interaction.

\section{Cell culture and transfections}

EB3 and Hela cells were maintained in complete RPMI medium (containing 10\% fetal calf serum and $0.1 \mathrm{mg} / \mathrm{ml}$ Penicillin G/Streptomycin). The EB3 and Daudi cells (both mature B cell lines derived from Burkitts lymphomas) were from ATCC and a gift of $\mathrm{T}$ Lebien respectively. Transfections of EB3 cells were done by electroporation using the Electro Cell Manipulator 6000 (BTX) at the following setting: $210 \mathrm{~V}, 800 \mu \mathrm{F}$ and $48 \mathrm{ohms}$. For each transfection, $1 \times 10^{7}$ cells were used along with $10 \mu \mathrm{g}$ of reporter constructs, various amounts of effector constructs as indicated in the figure legends and $2 \mu \mathrm{g}$ of pEFlacZ. Each transfection was adjusted to contain the same total amount of DNA by inclusion of the appropriate amount of empty parental expression vector. Transfections of Hela cells were done by the liposome-mediated method, using the $\mathrm{Tfx}-20^{\mathrm{TM}}$ reagent (Promega). Cells were plated one day prior to transfection. For immunofluorescence analyses, $4 \times 10^{5}$ cells were plated on coverslips in $60 \mathrm{~mm}$ plates. Each transfection contained $1 \mu \mathrm{g}$ each of BCL-6 and N-CoR expression constructs along with $6 \mu \mathrm{l}$ of $\mathrm{Tfx}-20^{\mathrm{TM}}$ reagent (yielding a $2: 1$ lipid to DNA ratio) in $1 \mathrm{ml}$ of serum free media. After $1 \mathrm{~h}$ incubation at $37^{\circ} \mathrm{C}, 2 \mathrm{ml}$ of complete media was added. For mammalian two-hybrid and repression analyses, $2.5 \times 10^{5}$ cells were plated on 6-well plates $\left(9.6 \mathrm{~cm}^{2}\right.$ well). Each transfection contained the amounts of reporter and effector constructs as indicated in the figure legends and $25 \mathrm{ng}$ of pCMVlacZ, along with $3.6 \mu 1$ of $\mathrm{TfX}-20^{\mathrm{TM}}$ reagent (yielding a $2: 1$ lipid to DNA ratio) in $1 \mathrm{ml}$ of serum free media. After $1 \mathrm{~h}$ incubation at $37^{\circ} \mathrm{C}$, $2 \mathrm{ml}$ of complete media was added. Each transfection was adjusted to contain the same total amount of DNA by inclusion of the appropriate amount of empty parental expression vector. For all transfections, cells were harvested $44-48 \mathrm{~h}$ post transfections.

\section{Immunofluorescence analyses}

Immunofluorescence analyses were done as described (Skinner et al., 1997). The primary antibodies, rabbit polyclonal anti-BCL-6 (N-3, epitope corresponding to amino acids 3-484; Santa Cruz) and mouse monoclonal anti-flag M2 (Kodak) were used at $1: 100$ and $1: 2000$ dilution respectively. The secondary antibodies, goat antirabbit conjugated to lissamine rhodamine (Accurate Chemical and Scientific) and goat anti-mouse conjugated to Cy2 (Jackson ImmunoResearch) were both used at 1:200 dilution.

\section{Other methods}

Binding site was performed as described (Pollock and Treisman, 1990; Bardwell and Treisman 1994) with $\triangle B C L-$ 6 containing a carboxy-terminal myc epitope-tag. $\beta$-gal and CAT assays were conducted as described (Hill et al., 1993). Site directed mutagenesis was carried out using GeneEditor $^{\mathrm{TM}}$ in vitro Site-Directed Mutagenesis System (Promega) according to the manufacturer's instructions. Mutants were verified by sequencing. Luciferase assays were performed according to protocols provided by Promega.

Autoradiograms and SDS gels were scanned using Adobe Photoshop $^{\mathbb{B}} 4.0$ and the computer images inserted into the figures.

\section{Acknowledgements}

We thank I Goldsmith for oligonucleotide synthesis; Christy Miller for construction of WT and MT1 reporters, and $G$ Aviles for assistance with yeast assays. We thank T Miki for his generous gift of the BCL-6 cDNA; R Evans for pCMX-SMRT; MG Rosenfeld for pCMX-NCoR; R Marais for EFplink2 and EFlacZ expression vectors; $\mathrm{H}$ Towle for mammalian GAL4 DNA binding domain expression construct and pCMVlacZ; R Baer for G5E1bLuc reporter plasmid; D Bernhlor for pAH205; G Smith for SalF17R DNA; D Zarkower for TRA-1 bait plasmid; and A Zelent for PLZF cDNA. VB would like to thank Richard Treisman in whose lab at the ICRF the BCL-6 site selection was performed. We thank G Evan for 9E10 antibody; S Elledge for yeast plasmids and advice; and $\mathrm{K}$ Gustafson for noticing the STAT binding site similarity. We thank D Zarkower, H Towle, B VanNess, G $\mathrm{Li}$, P Siliciano, J Little and S Snyder for critical reading of the manuscript. VB was supported by the Medical Research Council of Canada while in R Treisman's laboratory. This work was supported by the University of Minnesota Graduate School and NIH grant 5R29CA71540 from the National Cancer Institute.

\section{References}

Albagli O, Dhordain P, Bernardin F, Quief S, Kerkaert JP and Leprince D. (1996). Bioch. Biophys. Res. Comm., 220, $911-915$.
Albagli O, Dhordain P, Deweindt C, Lecocq G and Leprince D. (1995). Cell Growth Diff., 6, 1193-1198. 
Alland L, Muhle R, Hou H, Jr., Potes J, Chin L, SchreiberAgus N and DePinho RA. (1997). Nature, 387, 49- 55.

Bardwell VJ and Treisman R. (1994). Genes Dev., 8, 1664 1677.

Baron BW, Desai M, Baber LJ, Paras L, Zhang Q, Sadhu A, Duguay S, Nucifora G, McKeithan TW and Zeleznik-Le N. (1997). Genes Chrom. Cancer, 19, 14-21.

Baron BW, Nucifora G, McCabe N, Espinosa Rd, Le BM and McKeithan TW. (1993). Proc. Natl. Acad. Sci., 90, $5262-5266$.

Baron BW, Stanger RR, Hume E, Sadhu A, Mick R, Kerckaert JP, Deweindt C, Bastard C, Nucifora G, Zeleznik-Le N and McKeithan TW. (1995). Genes Chrom. Cancer, 13, 221-224.

Boshart M, Kluppel M, Schmidt A, Schutz G and Luckow B. (1992). Gene, 110, 129-130.

Cattoretti G, Chang CC, Cechova K, Zhang J, Ye BH, Falini B, Louie DC, Offit K, Chaganti RS and Dalla-Favera R. (1995). Blood, 86, 45-53.

Chang CC, Ye BH, Chaganti RS and Dalla-Favera R. (1996). Proc. Natl. Acad. Sci., 93, 6947-6952.

Chen JD and Evans RM. (1995). Nature, 377, 454- 457.

Chen W, Iida S, Louie DC, Dalla-Favera R and Chaganti RS. (1998). Blood, 91, 603-607.

Chen Z, Brand NJ, Chen A, Chen SJ, Tong JH, Wang ZY, Waxman S and Zelent A. (1993). Embo J., 12, 1161-1167.

Dalton S and Treisman R. (1992). Cell, 68, 597-612.

Dent AL, Shaffer AL, Yu X, Allman D and Staudt LM. (1997). Science, 276, 589-592.

Deweindt C, Albagli O, Bernardin F, Dhordain P, Quief S, Lantoine D, Kerckaert JP and Leprince D. (1995). Cell Growth Diff., 6, $1495-1503$.

Deweindt C, Kerckaert JP, Tilly H, Quief S, Nguyen VC and Bastard C. (1993). Genes Chrom. Cancer, 8, 149-154.

Dhordain P, Albagli O, Ansieau S, Koken MH, Deweindt C, Quief S, Lantoine D, Leutz A, Kerckaert JP and Leprince D. (1995). Oncogene, 11, 2689-2697.

Dhordain P, Albagli O, Lin RJ, Ansieau S, Quief S, Leutz A, Kerckaert JP, Evans RM and Leprince D. (1997). Proc. Natl. Acad. Sci. USA, 94, $10762-10767$.

Dorn R, Krauss V, Reuter G and Saumweber H. (1993). Proc. Natl. Acad. Sci. USA, 90, 11376-11380.

Durfee T, Becherer K, Chen PL, Yeh SH, Yang Y, Kilburn A, Lee WH and Elledge SJ. (1993). Genes Dev., 7, 555569.

Flenghi L, Ye BH, Fizzotti M, Bigerna B, Cattoretti G, Venturi S, Pacini R, Pileri S, Lo Coco F, Pescarmona E, Pelicci PG, Dalla-Favera R and Falini B. (1995). Am. J. Pathol., 147, 405-411

Fukuda TYT, Okada S, Hatano M, Miki T, Ishibashi K, Okabe S and Koseki HHS, Taniguchi M, Miyasaka N, Tokuhisa T. (1997). J. Exp. Med., 186, 439-448.

Gerasimova TI, Gdula DA, Gerasimov DV, Simonova O and Corces VG. (1995). Cell, 82, 587-597.

Goldman PS, Tran VK and Goodman RH. (1997). Recent Prog. Horm. Res., 52, $103-119$.

Grignani F, De Matteis S, Nervi C, Tomassoni L, Gelmetti V, Cioce M, Fanelli M, Ruthardt M, Ferrara FF, Zamir I, Seiser C, Grignani F, Lazar MA, Minucci S and Pelicci PG. (1998). Nature, 391, 815-818.

Guidez F, Ivins S, Zhu J, Soderstrom M, Waxman S and Zelent A. (1998). Blood, 91, 2634-2642.

He LZ, Guidez F, Tribioli C, Peruzzi D, Ruthardt M, Zelent A and Pandolfi PP. (1998). Nat. Genet., 18, 126-135.

Heinzel T, Lavinsky RM, Mullen TM, Soderstrom M, Laherty CD, Torchia J, Yang WM, Brard G, Ngo SD, Davie JR, Seto E, Eisenman RN, Rose DW, Glass CK and Rosenfeld MG. (1997). Nature, 387, 43-48.

Hill CS, Marais R, John S, Wynne J, Dalton S and Treisman R. (1993). Cell, 73, 395-406.

Hong SH, David G, Wong CW, Dejean A and Privalsky ML. (1997). Proc. Natl. Acad. Sci. USA, 94, $9028-9033$.

Horlein AJ, Naar AM, Heinzel T, Torchia J, Gloss B, Kurokawa R, Ryan A, Kamei Y, Soderstrom M, Glass CK and Rosenfeld MG. (1995). Nature, 377, 397-404.

Howard ST, Chan YS and Smith GL. (1991). Virology, 180, $633-647$.

Hsu HL, Wadman I and Baer R. (1994). Proc. Natl. Acad. Sci. USA, 91, 3181-3185.

Kaplan J and Calame K. (1997). Nucleic Acids Res., 25, $1108-1116$.

Kawamata N, Miki T, Ohashi K, Suzuki K, Fukuda T, Hirosawa S and Aoki N. (1994). Bioch. Biophys. Res. Comm., 204, 366-374.

Koonin EV, Senkevich TG and Chernos VI. (1992). Trends Biochem. Sci., 17, $213-214$

Li JY, English MA, Ball HJ, Yeyati PL, Waxman S and Licht JD. (1997a). J. Biol. Chem., 272, 22447-22455.

Li X, Lopez-Guisa JM, Ninan N, Weiner EJ, Rauscher FJ and Marmorstein R. (1997b). J. Biol. Chem., 272, 27324 27329.

Lin RJ, Nagy L, Inoue S, Shao W, Miller WH and Evans RM. (1998). Nature, 19, 811-814.

Lo Coco F, Ye BH, Lista F, Corradini P, Offit K, Knowles DM, Chaganti RS and Dalla-Favera R. (1994). Blood, 83, $1757-1759$.

Migliazza A, Martinotti S, Chen W, Fusco C, Ye BH, Knowles DM, Offit K, Chaganti RS and Dalla-Favera R. (1995). Proc. Natl. Acad. Sci. USA, 92, 12520-12524.

Miki T, Kawamata N, Arai A, Ohashi K, Nakamura Y, Kato A, Hirosawa S and Aoki N. (1994). Blood, 83, 217-222.

Mizushima S and Nagata S. (1990). Nucleic Acids Res., 18, 5322.

Nagy L, Kao HY, Chakravarti D, Lin RJ, Hassig CA, Ayer DE, Schreiber SL and Evans RM. (1997). Cell, 89, $373-$ 380 .

Numoto M, Niwa O, Kaplan J, Wong KK, Merrell K, Kamiya K, Yanagihara K and Calame K. (1993). Nucleic Acids Res., 21, 3767-3775.

Offit K, Lo Coco F, Louie DC, Parsa NZ, Leung D, Portlock C, Ye BH, Lista F, Filippa DA, Rosenbaum A and et al. (1994). N. Engl. J. Med., 331, 74-80.

Ohno H, Kerckaert JP, Bastard C and Fukuhara S. (1994). Jpn. J. Cancer Res., 85, 592-600.

Onizuka T, Moriyama M, Yamochi T, Kuroda T, Kazama A, Kanazawa N, Sato K, Kato T, Ota H and Mori S. (1995). Blood, 86, $28-37$.

Otsuki T, Yano T, Clark HM, Bastard C, Kerckaert JP, Jaffe ES and Raffeld M. (1995). Blood, 85, 2877-2884.

Pittaluga S, Ayoubi TA, Wlodarska I, Stul M, Cassiman JJ, Mecucci C, Van Den Berghe H, Van De Ven WJ and De Wolf-Peeters C. (1996). J. Pathol., 179, 145-150.

Pollock R and Treisman R. (1990). Nucleic Acids Res., 18, 6197-6204.

Reid A, Gould A, Brand N, Cook M, Strutt P, Li J, Licht J, Waxman S, Krumlauf R and Zelent A. (1995). Blood, 86, $4544-4552$.

Sande S and Privalsky ML. (1996). Mol. Endocrin., 10, 813 825.

Seol W, Mahon MJ, Lee YK and Moore DD. (1996). Mol. Endocrin., 10, 1646-1655.

Seyfert VL, Allman D, He Y and Staudt LM. (1996). Oncogene, 12, 2331-2342.

Skinner PJ, Koshy BT, Cummings CJ, Klement IA, Helin K, Servadio A, Zoghbi HY and Orr HT. (1997). Nature, 389, $971-974$.

Soderstrom M, Vo A, Heinzel T, Lavinsky RM, Yang W, Seto E, Peterson DA, Rosenfeld MG and Glass CK. (1997). Mol. Endocrinol., 10, 682-692.

Soeller WC, Oh CE and Kornberg TB. (1993). Mol. Cell. Biol., 13, $7961-7970$.

Stein H and Dallenbach F. (1992). Neoplastic hemtopathology. Knowles DM (ed). Williams and Wilkins: Baltimore, p. 675 . 
Tsukiyama T, Becker PB and Wu C. (1994). Nature, 367, $525-532$.

Tsukiyama T and Wu C. (1995). Cell, 83, 1011-1020.

Wall G, Varga-Weisz PD, Sandaltzopoulos R and Becker PB. (1995). EMBO J., 14, $1727-1736$.

Wilkinson JR and Towle HC. (1997). J. Biol. Chem., 272, $23824-23832$.

Xiong WC and Montell C. (1993). Genes Dev., 7, 1085-1096.

Ye BH, Cattoretti G, Shen Q, Zhang J, Hawe N, de Waard R, Leung C, Nouri-Shirazi M, Orazi A, Chaganti RS, Rothman P, Stall AM, Pandolfi PP and Dalla-Favera R. (1997). Nature Genet., 16, 161-170.

Ye BH, Chaganti S, Chang CC, Niu H, Corradini P, Chaganti RS and Dalla-Favera R. (1995). EMBO J., 14, $6209-6217$.
Ye BH, Rao PH, Chaganti RS and Dalla-Favera R. (1993). Bioch. Biophys. Res. Comm., 53, 2732-2735.

Zamir I, Harding HP, Atkins GB, Horlein A, Glass CK, Rosenfeld MG and Lazar MA. (1996). Mol. Cell. Biol., 16, $5458-5465$.

Zamir I, Zhang J and Lazar MA. (1997). Genes Dev., 11, $835-846$.

Zarkower D and Hodgkin J. (1992). Cell, 70, 237-249.

Zhang Y, Iratni R, Erdjument-Bromage H, Tempst $\mathrm{P}$ and Reinberg D. (1997). Cell, 89, 357-364.

Zollman S, Godt D, Prive GG, Couderc JL and Laski FA. (1994). Proc. Natl. Acad. Sci. USA, 91, 10717-10721. 